\title{
BIOCONTROL POTENTIAL OF SALINITY TOLERANT MUTANTS OF TRICHODERMA HARZIANUM AGAINST FUSARIUM OXYSPORUM
}

\author{
Hassan Abdel-Latif A. Mohamed ${ }^{1 *}$; Wafaa Mohamed Haggag² \\ ${ }^{1}$ Department of Microbial Genetics, National Research Center, Dokki, Cairo, Egypt; ${ }^{2}$ Department of Plant Pathology, National \\ Research Center, Dokki, Cairo, Egypt
}

Submitted: May 30, 2005; Returned to authors for corrections: September 22, 2005; Approved: February 26, 2006

\begin{abstract}
Exposing a wild-type culture of Trichoderma harzianum to gamma irradiation induced two stable salt-tolerant mutants (Th50M6 and Th50M11). Under saline conditions, both mutants greatly surpassed their wild type strain in growth rate, sporulation and biological proficiency against Fusarium oxysporum, the causal agent of tomato wilt disease. Tolerant $T$. harzianum mutants detained a capability to grow and convinced sporulation in growth media containing up to $69 \mathrm{mM} \mathrm{NaCl}$. In comparison with their parent strain, characterization of both mutants confirmed that they have reinforced contents of proline and hydroxyproline, relatively higher sodium content compared to potassium, calcium or magnesium contents, higher level of total phenols. Electrophoretic analysis of total soluble proteins in the salt tolerance mutant Th50M6 showed different bands accumulated in response to $69 \mathrm{mM} \mathrm{NaCl}$. Data also showed that mutants produce certain active metabolites, such as chitinases, cellulases, $\beta$-galactosidases, as well as, some antibiotics i.e., trichodermin, gliotoxin and gliovirin. Trichoderma mutants significantly reduced wilt disease incidence and improved yield and mineral contents of tomato plants under both saline and non-saline soil conditions, as well as, under infested and natural conditions. T. harzianum mutants were also more efficient in dropping the $F$. oxysporum growth in rhizosphere compared to the wild type strain. Population density of both mutants in rhizosphere far exceeded that of $T$. harzianum wild type strain.
\end{abstract}

Key words: antifungal metabolites, mutagenesis, $\gamma$-irradiation, salt stress, Trichoderma harzianum, Fusarium oxysporium

\section{INTRODUCTION}

Wilt disease caused by Fusarium oxysporum is among the most overwhelming disease in tomato (Lycopersicon esculentum L.) causing pensive economic expenditure (11). It is a rowdy disease because of the auspicious ecosystem needed for its development (9). El-Abyed et al. (13) and Ragazzi et al. (32) reported that mycelial growth and sporulation of different Fusarium species including $F$. oxysporum were motivated under salt stress conditions. Gour et al. (17) suggested that Fusarium infection might have contributed to wilting and yellowing of plants at high salinity levels.
Antagonistic Trichoderma species are considered as promising biological control agents against numerous phytopathogenic fungi including $F$. oxysporum (37). These filamentous fungi are very common in nature, with high population densities in soil and plant litters (36). They are saprophytic, promptly growing and easy to culture besides producing huge amounts of conidia with long lifetime.

One of the most crucial boundaries to use Trichoderma strains as biofungicides is their low osmotolerance level. Soil hydrological characters are considered as restraining parameters touching Trichoderma activities, most particularly spore germination, germ tube growth (25) and mycelial growth (24).

Corresponding Author. Mailing address: Department of Microbial Genetics, National Research Center, Dokki, Cairo, Egypt. Postal Code 1231. Tel.: (202) 366-99, Fax: (202) 337-0931. E-mails: habdo@nrc.org.eg; habdelltif@yahoo.com 
They also display a decisive outcome on saprophytic ability (14), on the interaction with other fungi (19), as well as on enzyme production (21).

Anthony (4) noticed that the halobacteria are the only microorganisms that are tolerant to salinity at the molecular level. All other bacteria, fungi, plants and animals need to be salt tolerant for most of their macromolecules through maintaining defined and conserved conditions in the cytoplasm. Salt tolerance of a given organism depends upon the range of external salinity over which it is able to sustain these conditions in the cytoplasm.

Mutation has been manipulated to improve production of antifungal metabolites and antagonistic potential of biocontrol agents to control a broad spectrum of phytopathogens (33). Several successful endeavors had been made to enhance the biocontrol potentiality of Trichoderma species by exposing the spores to chemical, e.g., EMS or physical mutagens, e.g., gamma ray (41). Breeding of Trichoderma is directed to achieve effective mycoparasitic strains for biocontrol against plant fungal pathogens under a wide range of adverse environmental conditions (26). More attention should be paid to the mutagenic methods of breeding, because strains bred by mutagenesis can easily get registration for field use from environmental protection agencies more than strains produced by protoplast fusion, transformation or via gene cloning.

In the present work, mutations in Trichoderma harzianum were induced by $\gamma$-irradiation for the sake of enhancing its biocontrol ability against Fusarium oxysporum and the production of antifungal metabolites under salt stress conditions. The selected salt-tolerant mutants were assessed to their antagonistic activity in comparison to their wild isolates in vitro as well as in vivo. Hydrolytic enzymes, i.e., chitinase, $\beta$ galactosidase and cellulase as well as some antibiotics and total phenols were also assayed under salt stress.

\section{MATERIALS AND METHODS}

\section{Fungal isolates and growth conditions}

A local isolate of Trichoderma harzianum Rifai was used throughout this study. Fusarium oxysporum f. sp. lycopersici was isolated from diseased tomato plants. Fungal isolates were maintained on potato dextrose agar (PDA) at $27^{\circ} \mathrm{C} \pm 1^{\circ} \mathrm{C}$. Potato dextrose broth (PDB) medium or czapek dox salt solution (CDS) was used to obtain the fungal culture filtrates. On desoxycholate agar medium (DAM), the growth was greatly restricted and the colonies did not exceed $2 \mathrm{~mm}$ in diameter.

\section{Mutants induction and characterization}

The salt-tolerant mutants were induced and isolated according to the methods of Gadgil et al. (16); Migheli et al. (27) and Rey et al. (33) with some modifications. PDA slants containing 14-day-old sporulated T. harzianum cultures were exposed to two dosages of $\gamma$-radiation (200 Gy for $75 \mathrm{~min}$ and 500 Gy by the dose rate 4.32 and $0.09 \mathrm{rad} / \mathrm{sec}$, respectively) provided from ${ }^{60} \mathrm{Co}$ source, installed at National Center for Radiation Research and Technology, Cairo, Egypt. Both irradiated and non-irradiated (control) conidia were harvested, re-suspended in physiological saline solution $(1.46 \mathrm{mM} \mathrm{NaCl})$ containing $0.1 \%$ Tween-80, to disperse spore clumps. Hemocytometer was applied for spore counting, while plate count was used for testing viability. Suitable dilution of the conidial suspension was plated onto DAM medium. The growing colonies were selected with respect to exhibiting phenotypic deviation from the parental strain and examined on PDA medium for some characters especially their antagonistic effects against $F$. oxysporum f. sp. lycopersici under saline stress conditions. The isolates that displayed good characters than the wild type isolate were selected and sub-cultured 7 times on PDA medium to test their stability. The tested cultures compared to the original ones and isolates, which maintained the original variation, were identified as mutants. Selected mutants were tested for their tolerance capacity to salinity.

\section{Laboratory tests}

Salt tolerance capacity of $T$. harzianum isolates was measured as percentage of reduction in linear growth that calculated by $(100 \times \mathrm{Y}-\mathrm{X} / \mathrm{Y})$, where $\mathrm{X}$ is the maximum radius $(\mathrm{mm})$ of the isolates grown on $\mathrm{NaCl}$ supplemented medium and $\mathrm{Y}$ is the radius of the isolates grown on $\mathrm{NaCl}$ free medium. Fungal growth was determined as colony diameter measurement but sporulation was identified as colony forming units (cfu). Antagonistic activity was measured as zone inhibition and growth reductions through dual culture on PDA medium or filtrate inhibition, where volume of each T. harzianum culture filtrate was added to PDA medium to provide a final concentration of $50 \%$, then inoculated with equal discs of the tested pathogen. Colonies diameters were determined after four days. Oven-dried $\left(65^{\circ} \mathrm{C}, 24 \mathrm{hr}\right)$ fungal samples were digested in mixture of sulfuric acid : perchloric acid $(5: 1, \mathrm{v} / \mathrm{v})$, and analyzed for further analytical determinations. Sodium $(\mathrm{Na})$ and potassium (K) concentrations were estimated by flame spectrophotometer. Magnesium $(\mathrm{Mg})$ and calcium $(\mathrm{Ca})$ concentrations were assayed by atomic absorption spectrophotometer. Free proline and its derivative hydroxyproline of T. harzianum isolates were extracted according to AAAOM (1) and estimated by the EPPENDORF Biotronik Amino Acid analyzer LC 3000. Protein extraction was carried out according to Bollag and Edelstein method (6). Total protein concentration was estimated according to Bradford method (8). Proteins taken from T. harzianum isolates after being grown on either CDS free or amended medium with $69 \mathrm{mM} \mathrm{NaCl}$ were separated by SDS-PAGE according to Laemmli (23). The gel was stained using silver stain according to Wray et al. (40) and distained with methanol solution. Molecular weights of polypeptide bands were 
calculated by AlphaImage ${ }^{\mathrm{TM}} 2200$ - MultiImage ${ }^{\mathrm{TM}}-$ AlphaInnoteeh company and low molecular weight marker kit of Phramacia (Uppsala, Sweden).Cultures filtrates of $T$. harzianum isolates were prepared by transferring equal discs (5-day-old) to 1-L Erlenmeyer flasks containing CDS free or amended with $69 \mathrm{mM} \mathrm{NaCl}$. After incubation for 10 days at $28^{\circ} \mathrm{C}$ on rotary shaking at $200 \mathrm{rpm}$, the cultures filtrates were removed and stored at $-20^{\circ} \mathrm{C}$ after extraction until used. The effect of saline medium on the activity of extracellular chitinase, cellulase and $\beta$-galactocidase were assessed in vitro with a microtiter plate spectrophotometer (Labsystems, Uniskan II) according to Boller et al.(7), Chernolazov et al. (10) and Antal et al. (3), respectively. Trichodermin, gliotoxin and gliovirin antibiotics, as well as total phenols were determined in the filtrates according to A.O.A.C. (5) and Roberts and Lumsden (34) methods and identified by HPLC using a reverse phase C 8 column and compared with a standard (Sigma chemicals).

\section{Pot trials}

Trichoderma wild type and the mutant isolates were used to protect tomato (var. Peto 86) against infection by $F$. oxysporum f. sp. lycopersici. Their effects were determined under both control (soil collected from Gezerit El Dahal location, Giza Governorate, Egypt with EC amounting to $0.4 \mathrm{mhs}$ ) and saline (soil collected from Noubaria location, Behera Governorate, Egypt with EC amounting $6.4 \mathrm{mhs}$ ) conditions. Pots ( $30 \mathrm{~cm}$ diameter) were inoculated with $F$. oxysporum $\mathrm{f}$. sp. lycopersici at $2 \times 10^{4}$ colony forming units (cfu) and $0.01 \%$ Tween-80. Seeds were soaked in the Trichoderma suspension at a rate of $10^{5}$ spores / $\mathrm{mL}$. Pots (5 replicates) were sown with five seeds and irrigated daily with saline solution (2800 ppm), while control treatment received only normal irrigation water. The percentage of wilt disease incidence, population counts of Trichoderma isolates and $F$. oxysporum $\mathrm{f}$. sp. lycopersici in the soil rhizosphere were calculated.

\section{Field trials}

Two successive field experiments were carried out at Noubaria Region, Behera Govarnorate, Egypt during 2000 / 2001 and $2001 / 2002$ seasons to evaluate the potentiality of $T$. harzianum wild-type and the selected mutant isolates in protecting tomato plants against infection with $F$. oxysporum $\mathrm{f}$. sp. lycopersici in a sandy loam soil. Chemical constituents of the soil were as follows: $\mathrm{Na} 740 \mathrm{ppm}, \mathrm{Ca} 520 \mathrm{ppm}, \mathrm{Mg} 267 \mathrm{ppm}$, $\mathrm{K} 16 \mathrm{ppm}$, bicarbonates $13.2 \mathrm{ppm}$ and EC $6.4 \mathrm{mmhos} / \mathrm{cm}$. A split plot design, with four replicates was used. Tomato seeds (var. Peto 86) were sown in trays containing $2 \%$ spore suspension of Trichoderma at a rate of $10^{5}$ spores $\mathrm{mL}^{-1}$ in a buffer containing $20 \mathrm{mM}$ glucose and $20 \mathrm{mM}$ potassium phosphate for 45 days. The field experimental was conducted in $1,500 \mathrm{~m}^{2}$ area. Tomato seedlings were transplanted $50 \mathrm{~cm}$ apart in rows of $1.5 \mathrm{~m}$ width. Fifty seeds were used for each replicate. Disease incidences were calculated during different growth periods. Population densities of both Fusarium (per gram soil) and Trichoderma (cfu $\times 10^{4}$ ) isolates in rhizosphere soil were scored monthly during the growth period. At harvest, yield parameters of tomato plants were gauged. Nitrogen (18), phosphorus (28) and potassium (31) contents in tomato shoots were determined.

\section{Statistical analysis}

The collected data were statistically computed using the software SPSS for Windows (release 7.5.1, Dec. 20, 1996, SPSS Inc.). Data were subjected to analyses of variance and treatment means were compared by an approximate Duncan's multipletest $(\mathrm{P}<0.05)$.

\section{RESULTS}

\section{Mutants selection and characterization}

Substantial adverse consequences towards the wild type of T. harzianum, in terms of growth, sporulation and antagonistic activity under $\mathrm{NaCl}$ salt stress up to $69 \mathrm{mM}$ are presented in Table 1. Percentage of reduction in the linear growth and spore production of the tested T. harzianum strain increased parallel to the increase in $\mathrm{NaCl}$ concentration. On the other hand, antagonistic activities of the tested $T$. harzianum against $F$. oxysporum were decreased with the increase in $\mathrm{NaCl}$ concentration. Correlations were significant at P> 0.01 indicating that the tested Trichoderma strain was sensitive to salinity.

Two dosages of $\gamma$-irradiation (200 Gy and $500 \mathrm{~Gy}$ ) were used to mutagenize T. harzianum conidia. From the surviving colonies, four isolates (Th20M53, Th50M6, Th50M11 and Th50M46) maintaining the original variation and performance, were selected and identified as stable mutants.

As shown in Table 2, reduction in linear growth of the isolated mutants was not exaggerated when exposed to $0.0,51$ and 69 $\mathrm{mM} \mathrm{NaCl}$. Meanwhile, T. harzianum (WT) displayed a reduction

Table 1. Effect of salt stress on growth, sporulation and antagonistic activity of $T$. harzianum against $F$. oxysporum.

\begin{tabular}{cccc}
\hline $\begin{array}{c}\mathrm{NaCl} \\
(\mathrm{mM})\end{array}$ & $\begin{array}{c}\text { Reduction in } \\
\text { linear growth } \\
(\%)\end{array}$ & $\begin{array}{c}\text { Spore } \\
\text { production } \\
\left(\text { cfu } ~ 10^{4}\right)\end{array}$ & $\begin{array}{c}\text { Antagonistic activity } \\
\text { (as zone } \\
\text { inhibition, mm) }\end{array}$ \\
\hline 0.0 & $0.0 \mathrm{e}^{*}$ & $93.2 \mathrm{a}$ & $0.3 \mathrm{a}$ \\
17 & $18.57 \mathrm{~d}$ & $83.3 \mathrm{~b}$ & $0.3 \mathrm{a}$ \\
34 & $37.14 \mathrm{c}$ & $53.3 \mathrm{c}$ & $0.2 \mathrm{ab}$ \\
51 & $55.71 \mathrm{~b}$ & $41.2 \mathrm{~d}$ & $0.0 \mathrm{~b}$ \\
69 & $75.37 \mathrm{a}$ & $21.2 \mathrm{e}$ & $0.0 \mathrm{~b}$ \\
\hline
\end{tabular}

*Values represent the percent of six replicates. Values in each column followed by the same letter are not significantly different $(\mathrm{P}<0.05)$. 
Table 2. Characterization of some $\gamma$-ray induced mutants from T. harzianum grown in different saline media.

\begin{tabular}{|c|c|c|c|c|c|c|c|c|c|}
\hline \multirow{3}{*}{$\begin{array}{l}\text { Trichoderma } \\
\text { isolates }\end{array}$} & \multirow{3}{*}{$\begin{array}{l}\mathrm{NaCl} \\
(\mathrm{mM})\end{array}$} & \multirow{2}{*}{\multicolumn{2}{|c|}{$\begin{array}{l}\text { Reduction in linear } \\
\text { growth }(\%)\end{array}$}} & \multicolumn{6}{|c|}{ Description } \\
\hline & & & & \multicolumn{2}{|c|}{ Growth } & \multicolumn{2}{|c|}{ Sporulation $^{5}$} & \multicolumn{2}{|c|}{ Color $^{6}$} \\
\hline & & $1^{\mathrm{st}}$ & $7^{\text {th }}$ & $1^{\mathrm{st}}$ & $7^{\text {th }}$ & $1^{\text {st }}$ & $7^{\text {th }}$ & $1^{\mathrm{st}}$ & $7^{\text {th }}$ \\
\hline \multirow[t]{3}{*}{ Wild type $^{1}$} & 0.0 & 0.0 & 0.0 & Flat & Flat & + & +0 & $\mathrm{Yg}$ & $\mathrm{Yg}$ \\
\hline & 51 & 49.3 & 49.3 & Cottony & Cottony & + & + & W & W \\
\hline & 69 & 53.1 & 53.1 & Cottony & Cottony & + & + & W & $\mathrm{W}$ \\
\hline \multirow[t]{3}{*}{ Th20M532 } & 0.0 & 0.0 & 0.0 & Flat & Flat & $+1+$ & +1+t & W g & $\mathrm{Wg}$ \\
\hline & 51 & 0.0 & 0.0 & Flat & Flat & H+H & +1++ & $\mathrm{W} \mathrm{g}$ & $\mathrm{Wg}$ \\
\hline & 69 & 0.0 & 0.0 & Flat & Flat & + & + & W & W \\
\hline \multirow[t]{3}{*}{ Th50M6 $6^{3}$} & 0.0 & 0.0 & 0.0 & Flat & Flat & +H+ & +1+t & $\mathrm{Dg}$ & $\mathrm{Dg}$ \\
\hline & 51 & 0.0 & 0.0 & Flat & Flat & +H+ & H+r & $\mathrm{Yg}$ & $\mathrm{Yg}$ \\
\hline & 69 & 8.89 & 8.89 & Flat & Flat & +H+ & H+r & $\mathrm{W}$ & $\mathrm{W}$ \\
\hline \multirow[t]{3}{*}{ Th50M113 } & 0.0 & 0.0 & 0.0 & Flat & Flat & $+1+$ & $H$ & $\mathrm{Dg}$ & $\mathrm{Dg}$ \\
\hline & 51 & 0.0 & 0.0 & Flat & Flat & $+1+$ & $+1+$ & $\mathrm{G}$ & $\mathrm{G}$ \\
\hline & 69 & 0.0 & 0.0 & Flat & Flat & $+1+$ & $H$ & G & $\mathrm{G}$ \\
\hline \multirow[t]{3}{*}{ Th50M463 } & 0.0 & 0.0 & 0.0 & Flat & Flat & +H+ & H+r & $\mathrm{G}$ & $\mathrm{G}$ \\
\hline & 51 & 0.0 & 0.0 & Cottony & Cottony & - & - & $\mathrm{W}$ & W \\
\hline & 69 & 0.0 & 0.0 & C. t. ${ }^{4}$ & C.t. ${ }^{4}$ & - & - & W & $\mathrm{W}$ \\
\hline
\end{tabular}

${ }^{1}$ T. harzianum Wild type (WT); ${ }^{2,3} 200$ and 500 Gy $\gamma$-ray induced mutants, respectively; ${ }^{4}\left(\mathrm{C}\right.$. t.) Convex type; ${ }^{5}(-)$ not disperse, $(+)$ little disperse, (++) moderate disperse; (+++) good disperse, (++++) compact; ${ }^{6}(\mathrm{Dg})$ Dark green, (G) Green, (Yg) Yellowish green, (Wg) Whitish green and $(\mathrm{W})$ White. $\left(1^{\text {st }}\right)$ First subculture, and $\left(7^{\text {th }}\right)$ Seventh subcultures.

in linear growth. The morphological growth of the isolated mutants and wild type was flat and cottony, respectively on natural or salt media. Furthermore, Th50M46 showed a convex type of growth at $69 \mathrm{mM} \mathrm{NaCl}$. In natural medium, the tested isolates exhibited compact spores except for Th50M11 and Th50M46 that showed good disperse spores. In salt medium $(51 \mathrm{mM} \mathrm{NaCl})$ most of the tested isolates produced compact spores, while Th50M11 showed good disperse spores. Regarding to spore color in natural medium, the mutants Th20M53 and Th50M46 formed green spores, while Th50M6 and Th50M11 bent dark green spores, T. harzianum (WT), twisted yellowish green spores, and Th20M53 produced whitish green spores. In salt medium $(51 \mathrm{mM} \mathrm{NaCl})$, the isolates WT and Th50M46 formed fashioned white spores Th20M53 produced whitish green spores, Th50M6 gave yellowish green spores, and Th50M11 created green spores. In salt medium (69 $\mathrm{mM} \mathrm{NaCl}$ ) the tested Trichoderma isolates exhibited white spores, and only Th50M11 displayed green spores.

Out of the isolated mutants that retained their tolerance to salt stress even after seven subcultures, the two mutants Th50M6 and Th50M11 were selected for further investigations. The effect of saline medium on linear growth, sporulation and antagonistic potential of the tested mutants are measured and described in Table 3. Generally, the growth of the tested Trichoderma isolates was affected by salt stress.
Nevertheless, mutant isolates were more tolerant to salt stress than their wild parents. In natural medium, while the mutant Th50M6 achieved a maximum radial growth after 4 days of incubation period, while the wild type and mutant (Th50M11) showed a delayed reduction in their linear growth reaching 52 and $4 \mathrm{~mm}$, respectively after the same period. In saline medium, the wild type, Th50M6 and Th50M11 showed a delayed reduction in their linear growth reaching 70,2 and $10 \mathrm{~mm}$, respectively after the same period. With regard to spore formation in the wild strain expressed as cfu x $10^{4}$, the selected mutants far exceeded their parents grown in either natural or saline medium at all incubation periods. Simultaneously, the mutant Th50M6 displayed a maximum antagonistic activity against $F$. oxysporum f. sp. lycopersici on either natural or saline medium compared to the wild strain that exhibited a distinct decrease in its biological control activity on saline medium than in natural one by 60 and $50 \%$, respectively. At the same time, $F$. oxysporum was completely inhibited when amended with 50\% culture filtrate of Th50M6 and Th50M11 compared with 74.5 and $12.6 \%$ of wild type at natural and saline medium, respectively.

The tested Trichoderma isolates were validated by their salt tolerance capacity through evaluating some ion contents (Fig. 1), the amino acid praline (Fig. 2), under salt stress conditions. Fig. 1 shows that magnesium $(\mathrm{Mg})$, calcium $(\mathrm{Ca})$ and potassium 
Table 3. Effect of saline medium on linear growth, sporulation and antagonistic potential of $T$. harzianum wild type and two of its selected mutants against $F$. oxysporum f. sp. lycopersici after (2 and 4), (10 and 30) and 6 days incubation, respectively

\begin{tabular}{|c|c|c|c|c|c|c|c|}
\hline \multirow{2}{*}{ Parameters } & \multirow{2}{*}{ Incubation days } & \multicolumn{2}{|c|}{ T. harzianum ${ }^{3}$} & \multicolumn{2}{|c|}{ Th50M6 ${ }^{4}$} & \multicolumn{2}{|c|}{ Th50M11 ${ }^{4}$} \\
\hline & & Natural $^{1}$ & Saline $^{2}$ & Natural $^{1}$ & Saline $^{2}$ & Natural $^{1}$ & Saline $^{2}$ \\
\hline \multirow{2}{*}{ Linear growth $(\mathrm{mm})^{5}$} & 2 & $22 c^{*}$ & $5 c$ & $75 a$ & $73 a$ & $70 \mathrm{~b}$ & $65 \mathrm{~b}$ \\
\hline & 4 & $38 \mathrm{~b}$ & $20 \mathrm{c}$ & $90 \mathrm{a}$ & $88 \mathrm{a}$ & $86 a$ & $80 \mathrm{~b}$ \\
\hline \multirow[t]{2}{*}{ Sporulation $\left(\mathrm{cfu} \times 10^{4}\right)^{6}$} & 10 & $195 c$ & $43 c$ & $1389 a$ & $1016 \mathrm{a}$ & $833 b$ & $736 \mathrm{~b}$ \\
\hline & 30 & $136 \mathrm{c}$ & $57 \mathrm{c}$ & 1944a & $1563 \mathrm{a}$ & $1314 b$ & $1023 b$ \\
\hline $\begin{array}{l}\text { F. oxysporum f. sp. lycopersici } \\
\text { growth reduction }(\%)^{7}\end{array}$ & 6 & $50 \mathrm{~b}$ & $40.4 \mathrm{c}$ & $100 \mathrm{a}$ & $100 \mathrm{a}$ & $98.6 \mathrm{a}$ & $94.3 \mathrm{~b}$ \\
\hline $\begin{array}{l}\text { F. oxysporum f. sp. lycopersici } \\
\text { growth reduction }(\%) \text { by } 50 \% \\
\text { culture filtrates }\end{array}$ & 6 & $74.5 \mathrm{~b}$ & $12.6 \mathrm{c}$ & $100 \mathrm{a}$ & $100 \mathrm{a}$ & $100 \mathrm{a}$ & $86 b$ \\
\hline
\end{tabular}

${ }^{1} \mathrm{PDA} \mathrm{NaCl}$ free medium; ${ }^{2} \mathrm{PDA}$ amended with $69 \mathrm{mM} \mathrm{NaCl}$ medium; ${ }^{3} \mathrm{Wild}$ type; ${ }^{4} 50 \mathrm{k}$ rad-induced mutants; ${ }^{5}$ after 2 and 4 incubation days; ${ }^{6}$ after 10 and 30 incubation days; ${ }^{7,8}$ after 6 incubation days; *Values represent the percent of six replicates. Values in each row followed by the same letter do not differ significantly $(\mathrm{P}<0.05)$.

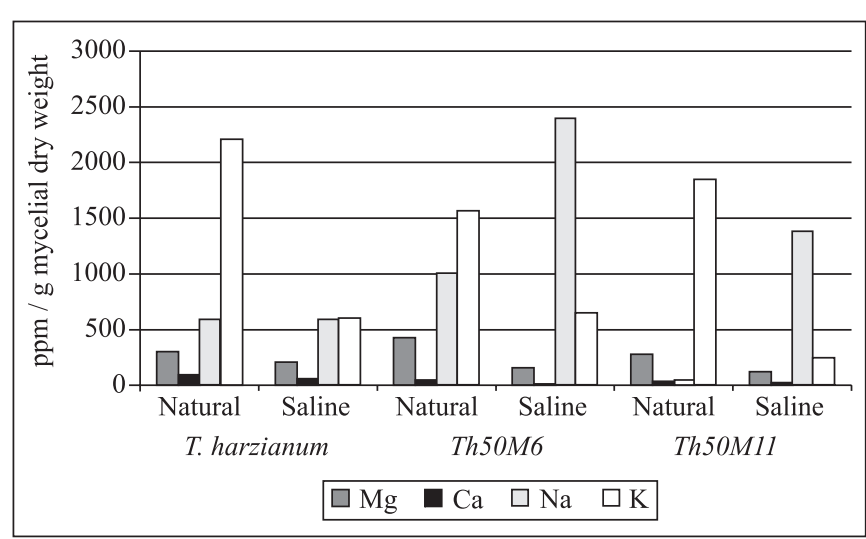

Figure 1. Effect of saline medium on $\mathrm{Mg}, \mathrm{Ca}, \mathrm{Na}$ and $\mathrm{K}$ contents in the mycelium of two $\gamma$-induced mutants from T. harzianum as well as their wild type.

* Natural and saline media are referring to PDA NaCl-free medium and PDA medium amended with $69 \mathrm{mM} \mathrm{NaCl}$, respectively. $* T$. harzianum is wild type isolate. ${ }^{* T h 50 M 6}$ and Th50M11 refer to $\gamma$-ray induced mutants.

(K) contents in the mycelia of both wild fungi and its selected mutants Th50M6 and Th50M11 were reduced by salinity. On the other hand, sodium ( $\mathrm{Na}$ ) content in the mycelia showed an increase when grown under saline conditions. Generally, the tested mutants showed favor potassium $(\mathrm{K})$ over sodium $(\mathrm{Na})$ under saline condition than natural condition.

The genetic improvement program via $\gamma$-irradiation made it possible to obtain a T. harzianum slat tolerant mutants Th50M6 that exhibited superiority in bio-controlling $F$. oxysporum

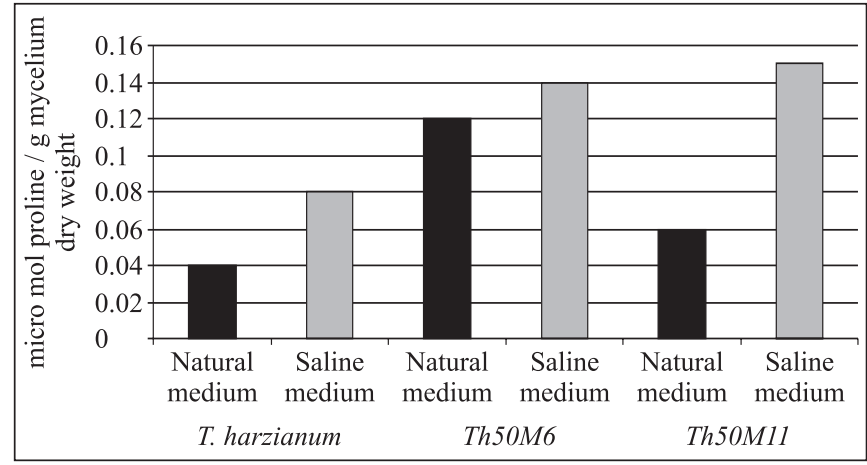

Figure 2. Effect of saline medium on proline contents. *Natural and saline media refer to PDA NaCl-free medium and PDA medium amended with $69 \mathrm{mM} \mathrm{NaCl}$, respectively. *T. harzianum is wild type isolate. ${ }^{\text {Th50M6 and Th50M11 }}$ refer to $\gamma$-ray induced mutants. **Proline content (proline and its derivative hydroxyproline) as $\mu \mathrm{g} / \mathrm{g}$ mycelium dry weight.

compared to its wild parent under salt stress conditions. SDSPAGE protein patterns were used as a molecular marker to distinguish between the selected mutant and its wild parent under salt stress conditions, verified that when the wild parent and the selected mutant Th50M6 were grown on PDB medium amended with $69 \mathrm{mM} \mathrm{NaCl}$, three polypeptide bands (130.43, 51.11 and $7.27 \mathrm{KDa}$ ) and eight polypeptide bands (164.22, $97.42,60.51,50.33,41.86,32.74,10.83$ and $7.27 \mathrm{KDa}$ ) respectively were newly expressed and their expression was confined to cultures grown in saline medium, while the tested fungi did not express these newly proteins when grown in PDB salt free medium (Fig. 3 and Table 4). 
Table 4. Relative mobility of polypeptide bands molecular weights of the wild type T. harzianum and their selected mutant Th50M6 under natural and salt stress conditions. As well as, low molecular weight standard protein marker in SDS-gel electrophoresis.

\begin{tabular}{|c|c|c|c|c|c|c|c|c|c|}
\hline \multicolumn{2}{|c|}{$\begin{array}{c}\text { Lane } 1 \\
\text { wild type } \\
\text { T. harzianum under } \\
\text { natural condition }\end{array}$} & \multicolumn{2}{|c|}{$\begin{array}{c}\text { Lane } 2 \\
\text { wild type } \\
\text { T. harzianum under } \\
\text { salt stress condition }\end{array}$} & \multicolumn{2}{|c|}{$\begin{array}{c}\text { Lane } 3 \\
\text { mutant Th50M6 } \\
\text { under natural } \\
\text { condition }\end{array}$} & \multicolumn{2}{|c|}{$\begin{array}{c}\text { Lane } 4 \\
\text { mutant Th50M6 } \\
\text { under salt stress } \\
\text { condition }\end{array}$} & \multicolumn{2}{|c|}{$\begin{array}{c}\text { Lane } 5 \\
\text { low molecular } \\
\text { weight standard } \\
\text { protein marker }\end{array}$} \\
\hline Band no. & M.W * & Band no. & M.W * & Band no. & M.W * & Band no. & M.W * & Band no. & M.W \\
\hline 18 & 182.87 & 13 & 130.43 & 10 & 143.20 & 1 & 164.22 & 1 & 20 \\
\hline 19 & 164.22 & 14 & 51.11 & 11 & 53.52 & 2 & 97.42 & 2 & 30 \\
\hline 20 & 134.50 & 15 & 14.28 & 12 & 9.43 & 3 & 60.51 & 3 & 43 \\
\hline 21 & 118.95 & 16 & 8.87 & & & 4 & 50.33 & 4 & 76 \\
\hline 22 & 58.70 & 17 & 7.27 & & & 5 & 41.86 & 5 & 94 \\
\hline 23 & 43.83 & & & & & 6 & 32.74 & & \\
\hline 24 & 29.85 & & & & & 7 & 10.83 & & \\
\hline 25 & 21.29 & & & & & 8 & 9.15 & & \\
\hline 26 & 14.96 & & & & & 9 & 7.27 & & \\
\hline 27 & 9.15 & & & & & & & & \\
\hline
\end{tabular}

*M.W is referring to molecular weights of polypeptide bands were calculated by AlphaImage ${ }^{\mathrm{TM}} 2200-$ MultiImage ${ }^{\mathrm{TM}}$ - AlphaInnoteeh company and low molecular weight marker kit of Phramacia (Uppsala, Sweden).

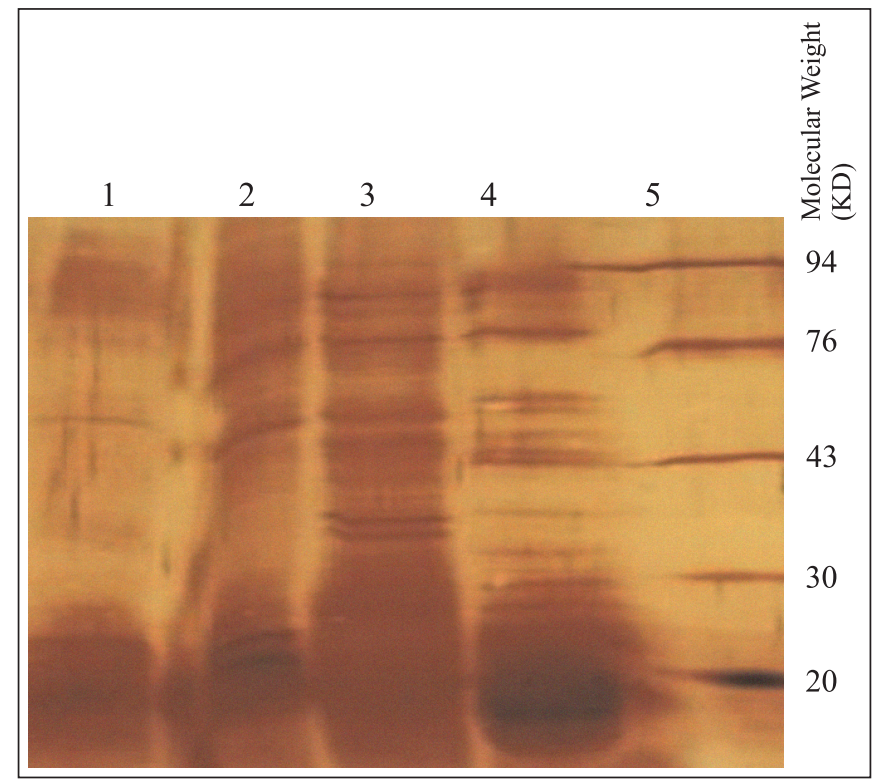

Figure 3. Protein profiles of the wild type T. harzianum (lanes 1 and 2) and their selected mutant Th50M6 (lanes 3 and 4) under natural (lanes 1 and 3) and salt stress (lanes 2 and 4) conditions. Low molecular weight standard protein marker is existed at (lane 5).

${ }^{1}$ Natural condition is referring to $\mathrm{PDB} \mathrm{NaCl}$ free medium; ${ }^{2}$ Stress condition is referring to PDB amended with $69 \mathrm{mM} \mathrm{NaCl}$ medium; ${ }^{3} \mathrm{Th} 50 \mathrm{M} 6$ is referring to $50 \mathrm{k}$-rad $\gamma$-induced mutant from the wild type parent $T$. harzianum.
The production of antifungal metabolites by the wild parent, Th50M6 and Th50M11 were affected negatively by salt stress (Table 5). However, the mutants showed less decrease than their wild type. In natural media, Th50M6 and Th50M11 produced the highest amounts of gliotoxin, gliovirin and trichodermin in contrast with salt conditions. Whereas, wild type showed reduction in gliotoxin, gliovirin and trichodermin production in natural media and under salt stress conditions. Furthermore, total phenols obtained from these mutants displayed increased amounts in control media and under salt stress conditions compared the with wild type. The same results hold true in extracellular hydrolysis enzymes production. Whereas, Th50M6 and Th50M11 produced more chitinase, cellulase and $\gamma$-galactosidase in control media and under salt stress conditions compared

\section{Pot trials}

The competency of T. harzianum wild type and their selected mutants on controlling Fusarium wilt of tomato under non-saline and saline soils infested with $F$. oxysporum is presented in Table 6 . The wilt disease incidence was higher in untreated plants either for non-saline or saline soils after 90 days of sowing. Wilt disease incidence showed highly decrease in non-saline and saline soils when the seeds dressed with the spores of wild type T. harzianum. But, dressing the seeds with the spores of mutants of $T$. harzianum resulted in a significantly greater decrease in the wilt disease incidence under non-saline and saline soils. Colonization of either F. oxysporum or Trichoderma isolates in 
Table 5. Inhibitory substances and extracellular hydrolysis enzymes produced by Trichoderma harzianum wild type and its mutants in their culture filtrates under natural and salt stress.

\begin{tabular}{|c|c|c|c|c|c|c|c|c|}
\hline \multirow{3}{*}{$\begin{array}{l}\text { Trichoderma } \\
\text { isolates }\end{array}$} & \multirow[t]{3}{*}{ Media } & \multicolumn{4}{|c|}{ Inhibitory substances } & \multicolumn{3}{|c|}{ Extracellular hydrolysis enzymes } \\
\hline & & Gliotoxin & Gliovirin & Trichodermin & Total phenols & Chitinase & Cellulase & $\beta$-galactosidase \\
\hline & & \multicolumn{7}{|c|}{$\mu \mathrm{g} / \mathrm{g}$ mycelial dry weight } \\
\hline \multirow[t]{2}{*}{ Wild type } & Natural $^{1}$ & 0.015 & 0.012 & 0.03 & 0.009 & 0.213 & 0.143 & 0.170 \\
\hline & Saline $^{2}$ & 0.005 & 0.004 & 0.01 & 0.002 & 0.080 & 0.010 & 0.020 \\
\hline \multirow{2}{*}{ Th50M6 ${ }^{3}$} & Natural $^{1}$ & 0.148 & 0.216 & 0.49 & 0.025 & 3.980 & 2.140 & 2.870 \\
\hline & Saline $e^{2}$ & 0.133 & 0.189 & 0.43 & 0.019 & 3.750 & 2.120 & 2.541 \\
\hline \multirow[t]{2}{*}{ Th50M11 $1^{3}$} & Natural $^{1}$ & 0.135 & 0.187 & 0.40 & 0.021 & 2.540 & 2.300 & 2.560 \\
\hline & Saline $^{2}$ & 0.112 & 0.163 & 0.34 & 0.018 & 2.330 & 2.150 & 2.424 \\
\hline
\end{tabular}

${ }^{1} \mathrm{PDB} \mathrm{NaCl}$-free medium; ${ }^{2} \mathrm{PDB}$ amended with $69 \mathrm{mM} \mathrm{NaCl}$ medium; ${ }^{3} \gamma$-ray induced mutants.

Table 6. Application efficiency of some Trichoderma harzianum isolates (wild-type and its mutants) on tomato wilt disease incidence after sown in non-saline and saline soils infested with F. oxysporum under pot experiments.

\begin{tabular}{|c|c|c|c|c|}
\hline $\begin{array}{c}\text { Trichoderma } \\
\text { treatment }\end{array}$ & Soil & $\begin{array}{l}\text { Wilt disease } \\
\text { incidence } \\
\%\end{array}$ & $\begin{array}{l}{ }^{3} \text { Population count } \\
\text { Fusarium } \\
\text { propagate / g soil }\end{array}$ & $\begin{array}{c}\text { Trichoderma } \\
\left(\text { cfu } \times 10^{5}\right)\end{array}$ \\
\hline \multirow[t]{2}{*}{ Untreated } & Non-saline $^{1}$ & $24.3 a^{5}$ & $19.4 a^{5}$ & - \\
\hline & Saline $^{2}$ & $21.6 \mathrm{a}^{5}$ & $15.2 \mathrm{ab}^{5}$ & - \\
\hline \multirow[t]{2}{*}{ T. harzianum (WT) } & Non-saline ${ }^{1}$ & $15.2 b^{5}$ & $9.3 b^{5}$ & $187.2 \mathrm{~d}^{5}$ \\
\hline & Saline $^{2}$ & $9.4 c^{5}$ & $7.4 b^{5}$ & $28.2 \mathrm{e}^{5}$ \\
\hline \multirow[t]{2}{*}{ Th50M6 $6^{4}$} & Non-saline $^{1}$ & $0.0 \mathrm{e}^{5}$ & $0.0 c^{5}$ & $462.3 a^{5}$ \\
\hline & Saline $^{2}$ & $0.0 \mathrm{e}^{5}$ & $0.0 c^{5}$ & $385.2 b^{5}$ \\
\hline \multirow[t]{2}{*}{ Th50M11 ${ }^{4}$} & Non-saline ${ }^{1}$ & $1.6 \mathrm{e}^{5}$ & $0.6 c^{5}$ & $402.3 b^{5}$ \\
\hline & Saline $^{2}$ & $0.6 \mathrm{e}^{5}$ & $0.3 \mathrm{c}^{5}$ & $312.6 c^{5}$ \\
\hline
\end{tabular}

${ }^{1}$ Soil obtained from Gezerit El Dahab location, Giza Governorate, Egypt, EC, $0.4 \mathrm{mmhos} / \mathrm{cm} ;{ }^{2}$ Soil obtained from Noubaria location, Behera Governorate, Egypt, EC $6.4 \mathrm{mmhos} / \mathrm{cm} ;{ }^{3}$ Wilt disease incidence was calculated after 90 days $;{ }^{4} \gamma$-ray induced mutants; $5 *$ Values represent the mean percentage of six replicates. Values in each column followed by the same letter are not significantly different $(\mathrm{P}<0.05)$.

tomato rhizosphere was assessed throughout 90 days growth period in control and saline soils. F. oxysporum propagates counts under non-saline and saline soils were non-detectable in the soils treated with the mutants Th50M6 and Th50M11 compared to soil treated with the wild type T. harzianum or untreated soil. At the same time, the selected Trichoderma mutants Th50M6 and Th50M11 showed significantly greater increase in their population densities as compared to the wild type T. harzianum in non-saline and saline soils.

\section{Field trials}

The effect of $T$. harzianum wild type and its selected mutants in controlling Fusarium wilt in tomato under salt or natural soils infested with $F$. oxysporum was assessed (Fig. 4). Data showed that wilt disease incidence was higher in untreated plants reaching 17.5 and $19.3 \%$ after 120 days of sowing during 2000/ 2001 and $2001 / 2002$ seasons, respectively. Treated plants with the wild type of $T$. harzianum decreased the incidence of wilt disease to 12.3 and $8.1 \%$, respectively. The mutants Th50M6 and Th50M11 possessed considerably higher biocontrol activity. No disease incidence was monitored in tomato plants receiving Th50M6, and a minimum level of disease symptoms was distinguished in those receiving Th50M11, which reached 1.6 and 1.9\% during 2000/2001 and 2001/2002 seasons, respectively. Colonization of either $F$. oxysporum or Trichoderma isolates in tomato rhizosphere was assessed 120 
days after sowing during 2001 / 2002 season (Fig. 4). Density of Fusarium was decreased with seed dressing by $T$. harzianum wild type (12.3 propagate /g soil) in comparison to untreated seeds (21.8 propagate /g soil) after 120 days. However, minimum propagates were recorded in the rhizosphere of tomato plants inoculated with Th50M6 and Th50M11 mutants reached to 1.6

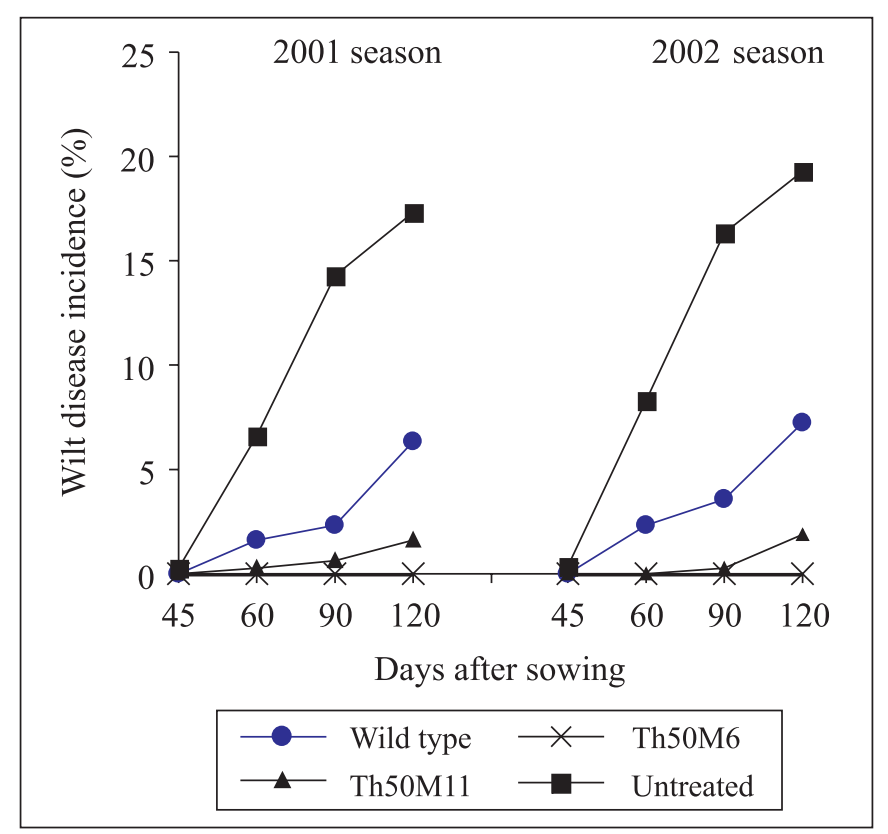

Figure 4. Application efficiencies of Trichoderma isolates on disease incidence of Fusarium oxysporum causing tomato wilt under field conditions $\mathbf{s}^{1,2}$.

${ }^{1}$ The experiments carried out at Noubaria Region, Behera Govarnorate, Egypt, during 2000 / 2001 and 2001 / 2002 seasons; ${ }^{2}$ (EC $\left.6.4 \mathrm{mmhos} / \mathrm{cm}\right)$. *Th50M6 and Th50M11 refer to $\gamma$-ray induced mutants. and 3.6 propagate /g soil, respectively after 120 days of sowing. At the same time, density of either Th50M6 or Th50M11 mutants were highly increased through 120 days up to 542.0 and 475.3 cfu x $10^{5}$, respectively compared to wild type $\left(8.1 \mathrm{cfu} \times 10^{5}\right)$. Table 7 shows the effect of applying $T$. harzianum wild type and its selected mutants on tomato plant yield and mineral content. Generally the different growth parameters were higher in plants treated with $T$. harzianum mutants than those treated with the wild type one. The increase in each of tomato plant yield and different minerals were significantly higher when associated with the mutants isolates than with either its wild type or untreated plants.

\section{DISCUSSION}

Salinity is one of the most widespread constraints to soil fertility (2). Preliminary investigations of Kredics et al. (21) proved that salt stress had significant detrimental effects towards growth, sporulation and antagonistic activity of the wild type isolate of T. harzianum against Fusarium oxysporum. Several successful trials had been made to increase the biocontrol potential of Trichoderma species under a wide range of adverse environmental conditions by exposing the spores to chemical e.g., EMS or physical mutagens, e.g., gamma rays (22). Mutation has been suggested to improve growth characters, antifungal metabolites production and antagonistic potential of $T$. harzianum against $F$. oxysporum under saline conditions.

One of the physiological adjustments in microbial growth at reduced water activity is the accumulation of specific intercellular substances as well as changes in their biosynthetic pathways (38), which are metabolically neutral osmolytes that might also be osmoprotectent (4). Sodium (Na) content of the tested Trichoderma isolates increased at saline medium, while $\mathrm{Ca} 2+, \mathrm{Mg} 2+$ and $\mathrm{K}+$ content decreased as previously detected by Khan et al. (20). On the other hand, the wild type T. harzianum

Table 7. Application efficiency of Trichoderma harzianum wild type and its mutants on growth,yield and minerals contents of tomato plants growing under field conditions ${ }^{1,2}$.

\begin{tabular}{|c|c|c|c|c|c|c|c|c|}
\hline \multirow{3}{*}{$\begin{array}{c}\text { Trichoderma } \\
\text { isolates }\end{array}$} & \multicolumn{4}{|c|}{ 2000/2001 season } & \multicolumn{4}{|c|}{ 2001/2002 season } \\
\hline & \multirow[t]{2}{*}{ Yield $\left(\mathrm{Kg} / \mathrm{m}^{2}\right)$} & \multicolumn{3}{|c|}{ Shoots mineral content $(\%)$} & \multirow[t]{2}{*}{ Yield $\left(\mathrm{Kg} / \mathrm{m}^{2}\right)$} & \multicolumn{3}{|c|}{ Leaf mineral content $(\%)$} \\
\hline & & $\mathrm{N}$ & $\mathrm{P}$ & $\bar{K}$ & & $\mathrm{~N}$ & $\mathrm{P}$ & $\bar{K}$ \\
\hline Wild type & $7.32 c^{4}$ & $3.21 \mathrm{~b}^{4}$ & $0.65 b^{4}$ & $3.61 b^{4}$ & $7.02 b^{4}$ & $3.65 b^{4}$ & $0.69 b^{4}$ & $3.67 b^{4}$ \\
\hline Th50M6 $6^{3}$ & $9.04 a^{4}$ & $4.11 \mathrm{a}^{4}$ & $0.92 \mathrm{a}^{4}$ & $4.03 \mathrm{a}^{4}$ & $8.75 a^{4}$ & $4.42 \mathrm{a}^{4}$ & $0.98 \mathrm{a}^{4}$ & $4.21 \mathrm{a}^{4}$ \\
\hline Th50M11 ${ }^{3}$ & $8.94 b^{4}$ & $4.01 \mathrm{a}^{4}$ & $0.81 \mathrm{a}^{4}$ & $3.98 \mathrm{a}^{4}$ & $8.65 a^{4}$ & $4.12 \mathrm{a}^{4}$ & $0.94 \mathrm{a}^{4}$ & $4.01 \mathrm{a}^{4}$ \\
\hline Untreated & $6.45 d^{4}$ & $2.78 c^{4}$ & $0.39 c^{4}$ & $3.31 \mathrm{c}^{4}$ & $6.31 c^{4}$ & $2.98 c^{4}$ & $0.41 \mathrm{c}^{4}$ & $3.36 c^{4}$ \\
\hline
\end{tabular}

${ }^{1}$ The experiments carried out at Noubaria Region, Behera Govarnorate, Egypt, during $2000 / 2001$ and $2001 / 2002$ seasons; ${ }^{2}$ (EC 6.4 mmhos $/ \mathrm{cm}) ;{ }^{3} \gamma$-ray induced mutants; ${ }^{4}$ Values represent the mean percentage of six replicates. Values in each column followed by the same letter are not significantly different $(\mathrm{P}<0.05)$. 
and its mutant isolates displayed an increase in their total proline derivatives when grown in the saline than in natural media. Peng et al.(30) results suggested that free proline always accumulates under osmotic stress conditions, however, upon removal of osmotic stress, proline levels return to normal. The results reveal that the removal of free proline during the recovery from salinity or dehydration stress engages an induction of proline dehydrogenase $(\mathrm{PDH})$ gene, while the activity of DELTA1-pyrroline-5-carboxylate-synthetase (P5CS) gene declines. The reciprocal regulation of P5CS and PDH genes appears to be a key mechanism in the control of proline levels during and after osmotic stress. PDH gene was also significantly induced by exogenously applied proline.

The effect of salinity on protein profiles of the slat tolerance mutant Th50M6 and salt sensitive wild strain resulted in different bands ranging between 164.22 and $7.27 \mathrm{KDa}$ accumulated in response to $69 \mathrm{mM} \mathrm{NaCl}$. These goes hand in hand with the findings reported by Sachs and Ho (35) who stated that salt stress caused alterations in gene expression led to the induction of new proteins and the repression of at least some normally expressed proteins. On the other hand, Ericson and Alfinito (15) reported that, several proteins are found to be more abundant in salt adapted cells of Nicotiana tabacum and another one of $25 \mathrm{KDa}$ is unique in salt adapted cells. When salt adapted cells are transferred to low salt medium, the levels of 20 and 32 KDa proteins return to those in the non-adapted cells. The 20 KDa proteins contained $4 \%$ hydroxyproline and $11.3 \%$ proline, which are unusually considered however being less than hydroxyproline-rich glycoproteins in cell walls. Also, Pareek et al. (29) referred that a $55 \mathrm{KDa}$ polypeptide is accumulated in response to high and low temperatures, salinity and desiccation stress conditions in shoots of rice seedlings

Since the production of antifungal metabolites, extra enzymes, and antibiotics appears to be responsible for the ability of Trichoderma strains to control the growth of pathogen -mediated wilt of tomato, it is hypothesized that superior biocontrol activity might be achieved by increasing production levels of these metabolites. In the current study, addition of $\mathrm{NaCl}$ to the growth medium at a rate of $69 \mathrm{mM} \mathrm{NaCl}$ increased metabolic activities of Trichoderma mutants including extra enzymes of chitinase, cellulose, $\beta$-galactosidase as well as the antibiotics, i.e., trichodermin, gliotoxin and gliovirin as well as total phenols compared to the wild type (39). The same results was showed by Abd-Alla and Omar (2), who stated that enzymatic activity of ten tested moulds including $T$. harzianum was strongly decreased by the addition of $\mathrm{NaCl}$ to the growth medium at the rates of either 0.5 or $1 \%$. The information about the influence of water conditions on metabolic activities of Trichoderma strains is essential for planning their application in biocontrol strategies. Kredics et al. (21) studied the influence of water potential on linear mycelial growth, secretion and in vitro activities of different enzymes of T. harzianum strain T66.
Optimal water potential values for the secretion of $\beta$-glucosidase, cellobiohydrolase, $\beta$-xylosidase, NAGase and chymotrypsin-like protease enzymes were different. Cellobiohydrolase and NAGase enzymes showed optimal secretion at the highest examined water potential, while the maximum activities of secreted $\beta$-glucosidase, $\beta$-xylosidase and chymotrypsin-like protease enzymes were transpired at lower water potential values than those optimal for growth. In vitro enzyme activities were exaggerated by water potential, but significant enzyme activities were measured for most of the enzymes even at -14.8 $\mathrm{MPa}$, which is below the water potential, where mycelial growth ceased. These results suggest the possibility of using mutants with improved xerotolerance for biocontrol purposes in soils with lower water potential.

In biological control experiments with tomato plants infested by F. oxysporum under saline soil (Na 740 ppm, Ca 520 ppm and EC $6.4 \mathrm{mmhos} / \mathrm{cm}$ ), mutants established a much better disease control, plant growth, yield and mineral content than the wild type. Overall, $F$. oxysporum population was minimized in soil rhizosphere together with a marked increase in the plant yield in comparison with the wild isolate. Such levels of plant protection were previously achieved using mutant strains through increasing the production of the extracellular antifungal metabolites (12). Overproduction of antifungal metabolites (enzymes or antibiotics) in Trichoderma mutants resulted in a reduced growth rate of the pathogen in vitro under saline soil conditions.

In conclusion, a new approach to develop improved biocontrol strains of Trichoderma harzianum by increasing salinity tolerance phenotype using mutation techniques was reached. Such an approach could be useful for enhancing salt tolerant, metabolic production and biocontrol ability against Fusarium oxysporum and protect tomato plants under saline conditions.

\section{ACKNOWLEDGMENTS}

The authors thank Prof. Dr. Hamdi Abouleid, the principal investigator of the project "Application of biotechnology in integrated management of pests and diseases in newly reclaimed areas in Egypt" funded by "The Egyptian Academy of Scientific Research and Technology" for his encouragement, the facilities provided and for reviewing the manuscript.

\section{RESUMO}

\section{Potencial de biocontrole de mutantes sal-tolerantes de Trichoderma harzianum contra Fusarium oxysporum}

A exposição de uma cepa selvagem de Trichoderma harzianum à irradiação gama induziu dois mutantes tolerantes a sal (Th50M6 e Th50M11). Em condições salinas, os dois mutantes foram muito superiores à cepa selvagem em relação à 
velocidade de multiplicação, esporulação e eficiência contra Fusarium oxysporum, o agente causador da doença wilt do tomate. Os mutantes tolerantes foram capazes de multiplicação e esporulação em meio de cultura contendo $\mathrm{NaCl}$ até $69 \mathrm{mM}$. Em comparação à cepa selvagem, os dois mutantes possuíam conteúdo mais elevado de prolina e hidroxiprolina, conteúdo de sódio superior ao de potássio, cálcio ou magnésio e conteúdo elevado de fenóis totais. A análise eletroforética das proteínas totais solúveis no mutante Th50M6 apresentou bandas diferentes acumuladas em resposta a $\mathrm{NaCl} 69 \mathrm{mM}$. Os resultados também indicaram que os mutantes produzem alguns metabólitos ativos como quitinases, celulases, $\beta$-galactosidades e antibióticos como tricodermina, gliotoxina e gliovirina. Os mutantes de Trichoderma reduziram significativamente a incidência da doença e melhoraram o rendimento e o conteúdo de minerais do tomate tanto em condições salinas como nãosalinas e também em condições naturais e de infestação. Quando comparados à cepa selvagem, os mutantes de Trichoderma foram também mais eficientes em diminuir o crescimento de $F$. oxysporum na rizosfera.A densidade populacional de ambos mutantes na rizosfera excedeu muito a da cepa selvagem.

Palavras-chave: metabólitos antifúngicos, mutagênese, irradiação gama, estresse salino, Trichoderma harzianum, Fusarium oxysporum

\section{REFERENCES}

1. AAAOM, Amino Acids Analyzer LC 3000 Operation Manual. Sample preparation for physiological fluids (Tissue extract). In: Manual version 4.1 of Eppendorf Biotronic Co., June 1998, p.65-81.

2. Abd-Alla, M.H.; Omar, S.A. Wheat straw and celluolytic fungi application increases nodulation, nodule efficiency and growth of fenugreek (Trigonella foenum-graceum L.) grown in saline soil. Biol. Fertil. Soils, 26, 58-65, 1998

3. Antal, Z.; Manczinger, L.; Szakacs, G.; Tengerdy, R.P.; Ferenczy, L. Colony growth, in vitro antagonism and secretion of extracellular enzymes in cold-tolerant strains of Trichoderma species. Mycol. Res., 104, 545-549, 2000.

4. Anthony, A. Molecular biology of salt tolerance in the context of whole-plant physiology. J. Exp. Bot., 49, 915-929, 1998.

5. A.O.A.C., Official Methods of Analysis of Association Official Agricultural Chemists, (12 ${ }^{\text {th }}$ Ed.). Washington, DC, 1975.

6. Bollag, D.M.; Eldelstein, S.J. Protein extraction. In: Protein methods. eda. Daniel M. Bollag and Stuart J. Eldelstein. Wiley-Liss Inc., New York, 1992, p.27-42

7. Boller, T.; Gegri, A.; Mauch, F.; Vogeli, U. Chitinase in bean leaves: induction by ethylene, purification, properties and possible function. Planta, 157, 22-31, 1983.

8. Bradford, M.M. A rapid and sensitive method for the quantitation of microgram quantities of protein utilizing the principle of proteindye binding. Anal. Biochem., 72, 248-254, 1976.

9. Campell, C.; Madden, L. Introduction to Plant Disease Epidemiology. New York: Wiley- Inter-Science, 1990.

10. Chernolazov, V.M.; Ermolora, O.V.; Uozny, U.V.; Klyosov, A.A. A Method for detection of cellulases in polyacrylamid gels using 5bromoindoxyl-B-cellobioside high sensitively and resolution. Anal. Bioch., 182, 250-251, 1989.
11. De Cal, A.; Pascual, S.; Melgarejo, P. A rapid laboratory method for assessing the biological control potential of Penicillium oxalicum against Fusarium wilts of tomato. Plant Pathology, 46, 699-707, 1997.

12. Dunne, C.; Moenne, L.; Bruijn, F.; O-Gara, F. Overproduction of an inducible extracellular serine protease improves biological control of Pythium ultimum by Stenotrophomonas maltophilia strain W81. Microbiology, 146, 2069-2078, 2000.

13. El-Abyad, M.S.; Hindorf, H.; Rizk, M.A. Impact of salinity stress on soil-borne fungi of sugar beet. II. Growth activities in vitro. Plant Soil, 110, 33-37, 1988.

14. Eastburn, D.M.; Butler, E.E. Effects of soil moisture and temperature on the saprophytic ability of Trichoderma harzianum. Mycologia, 83, 257-263, 1991.

15. Ericson, M.C.; Alfinito, S.H. Proteins produced during salt stress in tobacco cell culture. Plant Physiol., 74, 506-509, 1984.

16. Gadgil, N.; Daginawala, H.F.; Chokrabarti, T.; Khanna, P. Enhanced cellulase production by a mutant of Trichoderma reesei. Enzyme Microbial. Technol., 17, 942-946, 1995.

17. Gour, H.N.; Lal, P.; Mathur, J.R. Microbial population and yield of wheat in relation to soil salinity. J. Agronomy Crop Sci., 164, 100103, 1990.

18. Jackson, M. Soil chemical analysis. Constable and company Ltd. London, p. 498, 1962.

19. Jenog, M.; Jang, S.; Park, C. Influence of soil $\mathrm{pH}$ and salinity on antagonistic activity and rhizosphere competence of biocontrol agents. Korean J. Plant Pathol., 13, 416-420, 1997.

20. Khan, M.A.; Gul, B.; Weber, D.J. Effect of salinity on the growth and ion content of Salicornia rubra. Communications in Soil Sci. Plant Anal., 32, 2965-2977, 2001.

21. Kredics, L.; Antal, Z.; Manczinger, L. Influence of water potential on growth, enzyme secretion and in vitro enzyme activities of Trichoderma harzianum at different temperatures. Cur. Microbiol., 40, 310-314, 2000.

22. Kredics, L.; Antal, Z.; Manczinger, L.; Nagy, E. Breeding of mycoparasitic Trichoderma strains for heavy metal resistance. Let. Appl. Microbiol., 33, 112-116, 2001.

23. Laemmli, U.K. Cleavage of structural proteins during the assembly of the head bacteriophage T4. Nature, 224, 680-685, 1970.

24. Luard, E.J.; Griffin, D.M. Effect of water potential on fungal growth and tirgor. Trans. Br. Mycol. Soc., 76, 33-40, 1981.

25. Magan, N. Effects of water potential and temperature on spore germination and germ-tube growth in vitro and on straw leaf sheaths. Trans. Br. Mycol. Soc., 90, 97-107, 1988.

26. Manczinger, L.; Antal, Zs.; Kredics, L. Ecophysiology and breeding of mycoparasitic Trichoderma strains (a review). Acta Microbiol. Immunol. Hung., 49, 1-14, 2002.

27. Migheli, Q.; Gonzalez-Candelas, L.; Dealessi, L.; Camponogara, A.; Ramon, V.D. Transformants of Trichoderma longibrachiatum overexpressing the $\beta-1,4$-endoglucanase gene egl1 show enhanced biocontrol of Pythium ultimum on cucumber. Phytopathology, 88, 673-677, 1998 .

28. Olsen, S.R.; Sommers, L.E. Phosphorus. In: Miller, R.H.; Keeney, D.R. (eds) Method of Soil Analysis, part 2. Chemical and Microbiological Properties. American Society of Agronomy, Madison, 1982, p. 403-430.

29. Pareek, A.; Singla, S.; Grover, A. Evidence for accumulation of a 55 $\mathrm{kDa}$ stress-related protein in rice and several other plant genera. Plant Sci. Shannon, 134, 191-197, 1998.

30. Peng, Z.; Lu, Q.; Verma, D. Reciprocal regulation of DELTA1pyrroline-5-carboxylate synthetase and proline dehydrogenase genes controls proline levels during and after osmotic stress in plants. Mol. Gen. Genet., 253, 334-341, 1997.

31. Pipper, C. Soil and plant analysis. Interscience Publishers. Inc., New York, p. 368, 1950. 
32. Ragazzi, A.; Vecchio, V.; Dellavalle, I.; Cucchi, A.; Mancini, F. Variations in the pathogenisity Fusarium oxysporum f.sp. vasinfectum in relation to salinity of the nutrient medium. Z. Pflanzenkr. Pflanzenschutz, 101, 263-266, 1994.

33. Rey, M.; Delgado, J.J.; Rincon, A.M.; Limon, C.M.; Benitez, T.; Perez, E.A.; Cantoral, F.J. Improvement of Trichoderma strains for biocontrol. Micologia Industrial y Micopatotogia, 17, 531-536, 2000 .

34. Roberts, D.P.; Lumsden, R.D. Effect of extracellular metabolites from Gliocladium virens on germination of sporangia and mycelial growth of Pythium ultimum. Phytopathology, 80, 461-465, 1990.

35. Sachs, M.M.; Ho, T.H.D. Alteration of gene expression during environmental stress in plants. Ann. Rev. Plant Physiol., 37, 363376, 1986.

36. Samuels, G.J. Trichoderma: a review of biology and systematics of the genus. Mycol. Res., 100, 923-935, 1996.
37. Sarhan, M.M.; Ezzat, S.M.; Al-Tohamy, M.R. Application of Trichoderma hamatum as a biocontroller against tomato wilts disease caused by Fusarium oxysporum f. lycopersici. Egyptian J. Microbiol., 34, 347-376, 1999

38. Soliman, H.G.; El-Sheikh, H.H.; Lashine, I.F. Influence of salt stress on certain metabolic activities of Aspergillus terreus and A. tamarii isolated from the Mediterranean Sea water. Al-Azhar J. Microbiol., 24, 46-57, 1994.

39. Stefanova, M.; Leiva, A.; Larrinago, L.; Coronado, M.F. Metabolic activity of Trichoderma spp. isolates for a control of soil borne phytopathogenic fungi. Revista de la Faculad de Agronomia Universidad del Zulia, 16, 509-516, 1999.

40. Wray, W.; Boulinkas, T.; Wray, V.P.; Hancock, R. Silver staining of protein in polyacrylamid gel. Anal. Biochem., 118, 198-203, 1981.

41. Youssef, B.M.; Aziz N.H. Influence of gamma-irradiation on the bioconversion of rice straw by Trichoderma viride into single cell protein. Cytobios, 97, 171-183, 1999. 